\title{
Studi Living Al-Qur'an Pada Praktek Quranic Healing Kota Bengkulu (Analisis Deskriptif Terhadap Penggunaan Ayat-ayat Al-Qur'an)
}

\author{
Ahmad Farhan \\ Prodi Ilmu al-Qur'an dan Tafsir IAIN Bengkulu \\ Ahmad.farhan@gmail.com
}

\section{Pendahuluan}

Secara Al-Qur'an adalah representasi dari penjelmaan pesan-pesan universal Tuhan kepada hamba, hadir dalam bentuk teks verbal yang teraplikasikan dengan simbol-simbol bunyi yang mewakili firman Allah swt kepada Nabi Muhammad saw dengan menggunakan bahasa Arab. Sebagai wahyu dan petunjuk hidup bagi manusia, setiap muslim harus membaca, mehamami isinya serta mengaplikasikannya dalam kehidupan. Pembacaan yang dilakukan tentunya akan melahirkan pemahaman yang setiap muslim satu sama lainnya cenderung tidak sama. Hal ini menjadi niscaya karena terkait perbedaan kemampuan dan intensitas dalam membacanya. Dari pemahaman yang berbeda tadi, masing-masing juga akan melahirkan perilaku yang beragam pula Studi Living Al-Qur'an pada Praktek Quranic Healing Kota Bengkulu (Analisis Deskriptif terhadap Penggunaan Ayat-ayat Al-Qur'an) sebagai bentuk tafsir alQur'an dalam praksis kehidupan, baik pada wilayah teologis filosofis, psikologis maupun kultural.

Pengalaman dalam berinteraksi dengan al-Qur'an umumnya menghasilkan pemahaman dan penghayatan terhadap ayat-ayat al-Qur'an tertentu secara atomistik.1 Pemahaman dan penghayatan individual yang diungkapkan serta dikomunikasikan secara verbal maupun prilaku biasanya punya pengaruh kepada individu lain yang pada gilirannya dapat mengkosntruk kesadaran kolektif yang juga menciptakan tindakan dan perilaku dalam kehidupannya.2 Dalam praktek keberagamaan umat Islam, dapat ditemukan berbagai model pembacaan al-Qur'an. Baik yang berorientasi pada pemahaman dan pendalaman maknanya hingga yang sekedar membaca al-Qur'an sebagai ibadah ritual atau guna memperoleh ketenangan jiwa. Bahkan ada model pembacaan al-Qur'an yang berorientasi sebagai terapi pengobatan atau dianggap dapat mendatangkan kekuatan supranatural untuk mengusir jin dan sebagainya. 3 Dengan begitu dapat ditegaskan bahwa keberadaan al-Qur'an telah melahirkan berbagai bentuk respon yang beragam dan peradaban yang sangat kaya. Tidak berlebihan kiranya mengutip pendapat Naṣr Hāmid Abū Zayd yang 
menyatakan bahwa al-Qur'an sebagai produsen peradaban. (Muntij al-Saqā Dalam bahasa lain, fenomena ini merupakan sikap dan variasi respon muslim terhadap al-Qur'an.

Sebagai kitab suci, al-Qur'an dijadikan rujukan dan menjadi mitra dialog dalam menyelesaikan problem kehidupan yang dihadapi manusia. Oleh karenanya, menjadi maklum ketika kajian al-Qur'an umumnya banyak yang menekankan pada kajian teks al-Qur'an (baca: tafsir), dan produk tafsir (baca: pemikiran, penafsiran dan kitab tafsir) daripada kajian yang lain. Di lain sisi, terdapat model pemahaman berbeda dalam segi penerimaan al-Qur'an sebagai sebuah teks. Sementara al-Qur'an secara dogmatis adalah wahyu Allah yang memuat segala informasi, petunjuk dan regulasi untuk kebaikan umatnya. AlQur'an secara tekstual ditulis dengan bahasa Arab. Dengan demikian al-Qur'an mesti dibaca dan difahami dengan kapasitas teks bahasa Arab. 5 Dalam fakta sejarahnya, bahwa Nabi pernah melakukan ruqyah yaitu menyembuhkan penyakit dengan menggunakan ayat-ayat al-Qur'an. Sebagai contoh adalah penggunaan surat al-Mu'awwizatain ketika Nabi sakit dan di saat akan meninggal dunia. 6 Dari kasus di atas, dapat difahami bahwa al-Qur'an diperlakukan sebagai pemangku fungsi di luar kapasitasnya sebagai sebuah teks. Sebab, secara semantik surat al-Mu'awwizatain tidak memiliki korelasi dengan persoalan penyakit, akan tetapi terbukti digunakan untuk fungsi di luar fungsi semantisnya. Menurut peneliti, inilah satu fenomena sosial yang merupakan bentuk dari respon seseorang atau kelompok terhadap kehadiran al-Qur'an (baca: al-Qur'an yang hidup/living al-Qur'an) yaitu pengobatan penyakit dengan menggunakan ayat-ayat al-Qur'an.

Berdasarkan pemaparan di atas, tulisan ini akan menggali lebih lanjut dan concern pada praktisi ruqyah di Kota Bengkulu yang intens dalam melakukan pengobatan berbasis ayat-ayat al-Qur'an. Adalah Quranic Healing Bengkulu sebuah komunitas praktek ruqyah yang merupakan bagian dari keluarga besar Qur'anic Healing Indonesia yang berpusat di Kota Bandar Lampung.7 Praktisi ini telah mengikuti tahapan-tahapan yang ditentukan oleh komunitas Quranic Healing Indonesia seperti mengikuti training ruqyah dari para GM (Grand Master) Licensed Trainer (Certified Instructor) yang selanjutnya berhak untuk mendapatkan sertifikat Praktisi Quranic Healing (PQHi). Kemudian mengikuti Master Quranic Healing (MQHi): yaitu praktisi ruqyah aktif dan sudah menjadikan terapi ruqyah sebagai profesi seharihari dan atau memiliki klinik ruqyah. Para Master Quranic Healing (MQHi) direkomendasikan dan dipromosikan sebagai peruqyah profesional yang layak memberikan terapi 
ruqyah pada setiap orang yang membutuhkan pertolongan berhak untuk mendapatkan sertifikat Master Quranic Healing (MQHi)

\section{Signifikansi Kajian}

Kajian ini menjadi penting karena: Pertama, sebagai upaya dalam terus memperkenalkan model baru dalam penelitian al-Qur'an yang bertujuan untuk mengungkap respon seseorang atau komunitas muslim terhadap pembacaan, pemahaman dan pengamalan al-Qur'an. Kedua, penelitian living al-Qur'an dapat membuka pemahaman akan makna tafsir yang lebih luas, yaitu tafsir tidak hanya berupa menjelaskan apa yang ada dalam sebuah teks, tapi tafsir juga dapat berupa respon atau praktik perilaku suatu masyarakat.

\section{Metodologi Penelitian}

Tulisan ini didasarkan pada penelitian lapangan (field research) yang mengacu pada data primer dan data sekunder. Adapun data yang dimaksud adalah data kualitatif. Data ini terbagi pada data primer (primary resources) dan data sekunder (secondary resources). 8 Datar primer yang dimaksud adalah data dalam bentuk verbal atau kata-kata yang diucapkan secara lisan, gerak-gerik atas perilaku yang dilakukan oleh subyek-dalam hal ini adalah subyek penelitian (informan). Sedangkan data sekunder adalah daata yang diperoleh dari dokumen-dokumen grafis, foto, rekaman, video dan yang lainnya yang dapat menambah data primerSedangkan data sekundernya adalah bahan-bahan informatif baik berupa al-Qur'an, kitab hadis, bukubuku ulumul hadis, majalah, jurnal, artikel, dan webbsite yang layak dijadikan rujukan serta berkaitan dengan tema dan tujuan penelitian ini. Dalam penelitian ini, metode yang digunakan adalah metode deskriptif kualitatif). dengan pendekatan fenomenologi.10

Dalam melakukan penelitian ini, penulis mengumpulkan datadata penelitian dengan cara observasi, wawancara dan dokumentasi. Dalam rangka menguji kebasahan data yang telah diperoleh sehingga sesuai dengan tujuan dan maksud dari sebuah penelitian, maka peneliti menggunakan teknik triangulasi. Adapun triangulasi yang dimaksud dalam penelitian ini adalah triangulasi dengan sumber dan metode, yang berarti membandingkan dan mengecek balik kebenaran informasi dan data yang diperoleh melalui waktu dan alat yang berbeda dalam metode kualitatif. Hal ini dapat dicapai dengan cara sebagai berikut:

a. Membandingkan data dari berbagai sumber dengan data hasil observasi dan wawancara dengan praktisi Qurnanic Healing. 
b. Membandingkan data dari sumber yang sama dengan teknik yang berbeda, yang menggunakan data observasi, wawancara dan dokumentasi.

c. Membandingkan data dengan perspektif seseorang dengan berbagai pendapat orang lain yang lebih ahli dalam bidag yang sedang diteliti.11

Adapun teknik analisa yang digunakan adalah interactive model yang mengklasifikasikan analisa data kepada tiga langkah yaitu:12 Pertama, Reduksi data (Data Reduction) Reduksi data adalah suatu proses pemilahan, pemusatan perhatian pada penyederhanaan, pengabstrakan dan transformasi data kasar yang muncul dari catatan-catatan tertulis di lapangan. Kedua Penyajian data (Data Display) Data yang diperoleh dari hasil observasi dan wawancara akan disusun sedemikian rupa, sehingga memberikan kemungkinan adanya penarikan kesimpulan dan pengambilan tindakan. Ketiga, Penarikan kesimpulan (Verification). Dalam penelitian ini akan diungkap mengenai makna dari data yang dikumpulkan. Ketika ada keraguan, kekakuan dari kesimpulan yang ada, maka diperlukan verifikasi. Verifikasi ini dilakukan dengan meperhatikan kembali reduksi data maupun display data sehingga kesimpulan yang diambil tidak menyimpang atau sesuai dengan tujuan penelitian.

\section{Sekelumit tentang Quranic Healing Bengkulu}

Komunitas Quranic Healing Bengkulu merupakan sekumpulan anak muda yang punya perhatian dengan masalah akidah, khususnya terkait dengan adanya kepercayaan sebagian masyarakat dengan dukun, jimat, ilmu kebal dan lain sebagainya. Kegelisahan ini menjadikan Abū Zakwān terpanggil untuk berdakwah dan melakukan praktek ruqyah di Bengkulu. Singkatnya, Abū Zakwān mulai meruqyah dengan menggunakan istilah Quranic Healing dan akif mengadakan pelatihan Quranic Healing. Dari pelatihan tersebut, ada beberapa peserta pelatihan yang tertarik dan berkeinginan untuk menjadi praktisi Quranic Healing.

Dengan bergabungnya beberapa orang dalam komunitas ini, dan didasari dengan niat yang sama, maka disebutlah dengan Team Quranic Healing Bengkulu (QHB). Komunitas ini beranggotakan 5 orang yang aktif dalam melakukan pengobatan berbasis al-Qur'an dan doa-doa yang diajarkan Nabi, serta giat melakukan pelatihan ruqyah sebagai bagian dari syiar dan dakwah Islam. Sejauh pengamatan penulis, di antara anggota komunitas ini, maka Abu Zakwan, Abu Furqan dan Nopran yang cukup intens dan telah beberapa kali melakukan pelatihan Quranic Healing baik di kota Bengkulu maupun di luar kota Bengkulu seperti Arga Makmur, Seluma dan Rejang Lebong. Terkait ini 
ada latar belakang yang menghantarkan ketiga praktisi Quranic Healing menggeluti akitivitas ini. Sebagaimana hasil wawancara yang dilakukan bahwa menurut Abu Zakwan: "Pengobatan qurani atau Quranic Healing adalah satu ikhtiar kita dalam mengobati penyakit medis maupun non medis. Karena alQur'an juga berfungsi untuk penyembuhan (syifā) dan petunjuk (huda) bagi umat Islam. Tapi, harus difahami bahwa ini hanyalah ikhtiar kita, semua hasil dan kesembuhan hakiki adalah hak dan karena Alllah. Sebenarnya saya ke Bengkulu ini hendak mengembangkan medan dalam berdakwah. Karena saya adalah anggota Wahdah Islamiyyah di Makassar. Saya juga awalnya berjanji pada diri sendiri untuk tidak meruqyah lagi, karena saya pernah melakukannya di sana. Tapi, setelah sebulan dua bulan menetap di sini, saya melihat dan menemukan masih banyak orang-berdasarkan auranya- menggunakan sesuatu di tubuhnya, seperti imu pegangan, baik yang dia sengaja memasangnya, atau dipasangkan oleh orangtua atau kakeknya. Saya prihatin akan hal ini dan merasa terpanggil untuk melakukan ruqyah lagi. Karena ini penting untuk memurnikan akidah dan tauhid. 13 "Oleh karena saya prihatin dengan kondisi akidah di masyarakat, saya pun terpanggil untuk melakukan ruqyah Selanjutnya saya mendapatkan informasi tentang Quranic Healing Community. Kemudian saya mengikuti training untuk menjadi praktisi Quranic Healing sehingga mendapatkan sertifikati Praktisi Quranic Healing (PQHi), dilanjutkan pada level yang lebih tinggi yaitu Master Quranic Healing dengan sertifikatnya MQHi. Dari semua pelatihan tersebut, saya mendapat lisensi dan sertifikasi untuk melakukan ruqyah dan pelatihan ruqyah sebagai instruktur (Certified Instructor). Begitulah awalnya hingga sampai saat ini saya terus melakukan ruqyah terlebih pada kasus non medis seperti melepaskan buhul sihir pemisah suami isteri, seseorang yang menggunakan ilmu kebal, menggunakan jimat, mengalami perasaan takut, tidak tenang dan selalu dalam kecemasan"14

Sedangkan Abū Furqān menceritakannya sebagai berikut: "Sebenarnya saya udah lama mengenal ruqyah sejak masih kuliah, tapi belum mengerti lebih jauh. Saya juga anti kepada pengobatan kepada dukun, atau pengobatan yang dilakukan seseorang yang berkedok ustad tapi prakteknya berbau syirik. Maka, saya mencoba mencari-cari informasi tentang ruqyah. Ketika membaca majalah Ghaib yang di dalamnya ada berita tentang ruqyah yang dilakukan oleh ustad Fadlan, barulah saya mulai mengerti bahwa al-Qur'an bisa dijadikan pengobatan (Syifā). Pada tahun 2014, saya mendapatkan informasi tentang Quranic Healing di Bengkulu yang dilakukan oleh Abū Zakwān. Setelah saya 
telusuri, ternyata ada kaitannya dengan ustad Fadlan. Oleh karena itu, saya makin tertarik dengan ruqyah dan mengikuti pelatihan dengan Abū Zakwān.15

Selanjutnya Nopran menceritakannya seperti berikut ini: "Awalnya saya tahu tentang Quranic Healing adalah ketika ada pelatihan yang dilakukan oleh Abū Zakwān di Masjid al-Nur Lingkar Barat. Tetapi saya belum tertarik dengan pelatihan itu sendiri. Ketika ada saudara saya yang mengalami kesurupan hingga jam 2 malam, para keluarga bingung dan panik sampai kemudian ada yang menghubungi dukun. Proses pengobatan dilakukan dengan membaca mantra sambil komat-kamit plus menggunakan jurus-jurus. Keesokannya saya sarankan kepada keluarga untuk membawa saudara ke Abū Zakwān untuk agar dilakukan ruqyah."16

\section{Praktisi Quranic Healing dan Pemaknaannya terhadap al-Qur'an.}

Al-Qur'an merupkan kitab yang menjadi bacaan sekaligus menjadi petunjuk bagi orang beriman. Ahmad Rafiq mengklasifikasikan tujuan seseorang dalam membaca al-Qur'an kepada tiga kelompok. Pertama, membaca al-Qur'an sebagai ibadah. Hal ini didasarkan pada definisi al-Qur'an secara umum yang difahami oleh umat Islam.17 Karena secara subtantif, hanya alQur'an yang jika dibaca akan bernilai pahala. Pemahaman ini menjadi kuat di tengah kehidupan, sehingga banyak aktivitas membaca al-Qur'an yang dilakukann umat Islam sperti setelah sholat 5 waktu atau pada kegiatan dan acara tertentu lainnya.

Kedua, membaca al-Qur'an untuk mendapatkan petunjuk atau hidayah. Kedudukan al-Qur'an sebagai petunjuk telah disebutkan Allah Swt dalam QS. al-Baqarah/2: 2 yang berbunyi "zlālik al-Kitāb lā rayba fìhì hudan li alMuttaqin. "Oleh karena itu, sebagai regulasi utama bagi umat Islam, semua apa yang bersumber dari al-Qur'an menjadi prinsip dalam kehidupan. Ketiga, membaca al-Qur'an untuk mendapatkan justifikasi. Dalam kaitan ini, pembaca menggunakan bagian tertentu dari al-Qur'an untuk mendukung ide dan gagasan ataupun keadaan tertentu. Orang terlebih dahulu berhadapan dengan satu persoalan kemudian mencari bagian-bagian dari al-Qur'an untuk memberikan nilai pada keadaan tersebut, baik mendukung ataupun menolaknya, tergantung pada si pembaca. 18

Selain itu, jika kita perhatikan dengan seksama kehadiran alQur'an di tengah kehidupan umat Islam di Indonesia, maka akan terlihat adanya berbagai pemaknaan terhadap al-Qur'an sebagai sebuah kitab yang berisi firman Allah Swt dalam bahasa Arab dan ditulis dengan menggunakan huruf Arab. (QS. Yusuf/12: 2)19. Menurut Heddy Shri Ahimsa Putra, salah seorang pakar 
Antropologi UGM, bahwa pemaknaan terhadap al-Qur'an yang tampak pada kehidupan masyarakat muslim terdapat dalam beberapa klasifikasinya.20

Menurut Abū Zakwān, al-Qur'an adalah pegangan hidup yang harus diyakini kebenarannya, termasuk sebagai pengobatan (syifä). Dia menyebutkan firman Allah dalam QS. al-Isra/17: 82. Oleh karena itu, seorang muslim harus yakin bahwa al-Qur'an dapat memberikan kesembuhan atas segala penyakit baik medis maupun non medis.

Sedangkan Abū Furqān memaknai al-Qur'an sebagai bacaan dan falsafah hidup bagi umat Islam. Dia sangat yakin terhadap apa yang disebutkan dalam al-Qur'an, baik persoalan akidah, ibadah termasuk al-Qur'an berfungsi sebagai syifā atau penyembuh atas penyakit. Dia juga merujuk pada QS. al-Isra/17: 82 sebagaimana Abū Zakwān.

Hal yang tidak jauh berbeda diungkapkan oleh Nofran ketika peneliti mempertanyakan bagaimana pemaknaannya terhadap alQur'an. Menurutnya al-Qur'an merupakan firman Allah Swt yang diturunkan kepada Nabi Muhammad Saw dan disampaikan kepada kita semua untuk dijadikan petunjuk dalam kehidupan. Oleh karenanya, sebagai petunjuk kita wajib mengikuti petunjuk itu sehigga kita akan selamat baik di dunia maupun akhirat. Di antara pentujuk itu, Nofran menyebutkan bahwa al-Qur'an telah menginformasikan kepada kita sebagai obat dan rahmat bagi orang-orang beriman.

Oleh karenanya, semua praktisi secara umum punya pemaknaan yang tidak jauh berbeda terhadap al-Qur'an. Abū Zakwān memaknai al-Qur'an sebagai pegangan hidup yang harus diyakini kebenarannya, termasuk sebagai pengobatan (syifā). Ditambah dengan keyakinan yang teguh, secara totalitas, dan berpasrah kepada Allah, maka tidak ada penyakit yang tidak disembuhkan dengan al-Qur'an. Adapun Abū Furqān memaknai al-Qur'an sebagai bacaan dan falsafah hidup bagi umat Islam. Dia sangat yakin terhadap apa yang disebutkan dalam al-Qur'an, baik persoalan akidah, ibadah termasuk al-Qur'an berfungsi sebagai syifā atau pen yembuh atas penyakit. Sedangkan Nofran memaknai al-Qur'an sebagai firman Allah yang diturunkan kepada Nabi Muhammad dan disampaikan kepada kita semua untuk dijadikan petunjuk dalam kehidupan. Salah satu petunjuk itu adalah terkait dengan pengobatan yang bisa dilakukan berdasaran ayat-ayat al-Qur'an. Mengutip Sri Heddy Ahimsa-bahwa al-Qur'an dimaknai sebagai obat jasmani dan rohani21. Dalam hal ini, pemfungsian alQur'an tidak mengacu pada pemahaman atas pesan tekstualnya, tetapi berlandaskan keyakinan adanya "fadhilah" dari unit-unit tertentu teks al-Qur'an sehingga digunakan dalam praktek Quranic Healing. 


\section{Ayat-ayat yang digunakan dalam praktek Quranic Healing.}

Dalam wawancara yang dilakukan penulis kepada Abū Zakwān terkait ayat-ayat yang digunakan pada Quranic Healing, secara umum disebutkan bahwa seluruh ayat-ayat al-Qur'an bisa dijadikan dasar untuk pengobatan. Hal ini didasarkan firman Allah bahwa al-Qur'an diturunkan sebagai obat dan rahmat (QS. al-Isra/17: 82). Penulis kemudian memetakan ayat-ayat yang digunakan dalam praktek Quranic Healing secara akumulatif yaitu berjumlah 75 ayat yang terdiri dari QS. al-Fātiḥah/1: 1-7, QS. al-Baqarah/2: 102-103, 255, 284-286, QS. ali Imrān/3: 18-19, QS. al-Nisā/4: 56, QS. al-A'rāf/7: 54, 117122, QS. Yūnus/10: 57, 81-82, QS. Tāha/20: 69-70, QS. al-Mukminūn/23115-118, QS. al-Ṣāffāt/37: 1-10, QS. al-Aḥqāf/46: 29-32, QS. al-Raḥmān/55: 33-36, QS. al-Hasyr/59: 21-24, QS. alJīn/72: 1-9, QS. al-Ikhlaș/112: 1-4, QS. al-Falaq/113: 1-5 dan QS. al-Nās/114: 1-6. Abū Zakwān juga menjelaskan bahwa ayat-ayat yang disebutkan di atas, dalam prakteknya dipilah dan digunakan berdasarkan kasus atau penyakit yang akan disembuhkan. Secara umum, ketika pasien meminta untuk diruqyah karena penyakit medis maupun non medis, maka ayat yang digunakan adalah dikategorikan pada ayat ruqyah "sapu jagad" yaitu QS. al-Fātiḥah/1: 1-7, QS. alBaqarah/2: 255 (Ayat Kursi), QS. Ikhlas/112: 1-4\}, QS. al-Falaq/113: 1-5 dan QS. al-Nās/114: 1-6.

Abū Furqān secara umum menggunakan QS. al-Fatihah/1:1-7, QS. alBaqarah/2: 255 (Ayat kursi), QS. al-Ikhlaṣ/112: 1-4, QS. al-Falaq/113: 1-5 dan QS. al-Nās/114: 1-6. Semua ayat-ayat ini dibacakan secara berurutan ketika mulai melakukan ruqyah. Kemudian menggunakan ayat-ayat tertentu lainnya yang dirasa sesuai dengan kondisi penyakit pasien, seperti QS. al-Isrā/17: 82 dan QS. al-Hasyr/59: 21 untuk penyembuhan. Ada juga untuk mengangkat sihir dan mendakwahi jin yaitu QS. al-Baqarah/2: 102 dan QS. FaTir/25: 10.

Sedangkan Nofran menyatakan bahwa dirinya juga menggunakan ayat-ayat umum dalam praktek Quranic Healing yaitu QS. al-Fatihah/1: 1-7, QS. alBaqarah/2: 255, QS. al-Ikhlaṣ/112: 1-4, QS. al-Falaq/113: 1-5 dan QS. alNās/114: 1-6. Selama ini, ayat-ayat yang disebutkan punya pengaruh dan efek terhadap pengobatannya. Karena dia yakin akan kebenaran al-Qur'an dan kehendak Allah.

\section{Keutamaan ayat-ayat yang digunakan dalam praktek Quranic Healing.}

Abū Zakwān menyebutkan secara umum bahwa dalam hadis Bukhari disebutkan keutamaan surat al-Baqarah khususnya ayat kursi yang diyakini dapat memberikan perlindungan kepada pembacanya dari gangguan atau kejahatan makhluk-makhluk halus. Sedangkan ayat-ayat QS. al-Ikhlaș/112: 1-4, 
QS. al-Falaq/113: 1-5 dan QS. alNās/114: 1-6 dipillih untuk digunakan dalam pengobatan didasarkan kepada hadis Nabi yang diriwayatkan Abu Dāud tentang keutamaan surat al-surat Muawwi Zatain.

Lain halnya dengan Abū Furqān yang menjelaskan bahwa ayat-ayat yang digunakan pada praktek Quranic Healing pada prinsipnya bisa untuk segala penyakit. Pemahamannya berbasis pada pemaknaan al Qur'an yang dapat dijadikan obat. Tapi, Abū Furqān tidak menampik bahwa ayat-ayat tertentu yang digunakan dalam Quranic Healing secara umum punya fadhilahnya. Semisal QS. al-Fatihah/1: 1-7 yang merupakan surat pembuka dalam alQur'an.

Sementara Nopran, selaku anggota Quranic Healing yang-menurut peneliti- adalah termasuk yunior dibandingkan dengan Abū Zakwān dan Abū Furqān menjelaskan bahwa baginya al-Qur'an itu sendiri memang sebuah mukjizat yang dapat berfungsi untuk pengobatan. Sehingga ayat-ayat yang digunakan dalam Quranic Healing memang ayat-ayat yang punya keutamaan dan keterkaitan dengan pengobatan atau penyembuhan penyakit. Seperti yang disebutkan sebelumnya, bahwa secara umum Nofran menggunakan QS. alFātihahah/1: 1-7.

Oleh karenanya, semuanya secara umum menyatakan adanya keutamaan ayat-ayat yang digunakan dalam praktek Quranic Healing. Ketiganya juga sangat menyakini al-Qur'an dapat dijadikan sebagai penyembuh dari penyakit medis maupun non medis. Dengan demikian, ayat-ayat ayang digunakan telebih dahulu dilihat riwayat hadis yang menguatkan tentang ayat tersebut, selanjutnya melihat arti dan terjemahan ayat yang dimaksud. Hal ini menjadi penting untuk memudahkan dalam penyembuhan pasien.

\section{Korelasi hermeneutika antara ayat-ayat yang digunakan dengan penyakit yang disembuhkan.}

Abū Zakwān menyatakan bahwa ayat yang digunakan dalam praktek Quranic Healing umumnya digunakan sejalan dengan penyakit yang akan disembuhkan, bahkan dicarikan korelasi makna dari ayat dengan penyakit tersebut.

Subyek kedua, mengatakan bahwa dalam praktek Quranic Healing, dirinya tidak mengkultuskan ayat-ayat yang akan digunakan. Tapi tidak juga menafikan makna dan korelasinya dengan penyakit yang akan disembuhkan. Hal ini bisa saja berlaku pada satu kasus dan tidak pada kasus yang lainnya.

Subyek ketiga mengatakan bahwa dirinya dalam melakukan pengobatan tidak terlalu menghubungkannya dengan ayat-ayat tertentu. Secara umum, 
ayat-ayat yang telah dia ketahui itulah yang dibacakan dan diperdengarkan kepada orang yang sedang sakit. Meski begitu, dia harus mengetahui arti ayat dan hubungannya dengan penyakitnya sehingga diharapkan punya efek terhadap kesembuhannya.

Dari temuan dan analisa penulis, dapat dijelaskan kepada: Pertama, ayat-ayat yang secara implisit berhubungan dengan penyakit berjumlah 50 ayat yang terdiri dari QS. al-Fātiḥah/1: 1-7, QS. a-Baqarah/2: 255, 284-286, QS. al-A'rāf/7: 117-122, QS. al-Isrā/17: 82, QS. Tāhā/20: 69, QS. alMukminūn/23: 115-118, QS al-S\{äffāt/37: 1-10, QS. alHasyr/59: 21-24, QS. al-Ikhlaṣ/112: 1-4, QS. al-Falaq/113: 1-5 dan QS. al-Nās/114: 1-6.

Kedua, ayat-ayat yang secara eksplisit berhubungan dengan peyakit yang disembuhkan berjumlah 20 ayat yang terdiri dari QS. al-Baqarah/2: 102-103, QS. al-A'rāf/7: 54-56, QS. Yunūs/10: 57, 81-82, QS. alRaḥmān/55: 33-36 dan QS. Jinn/72: 1-9. Ketiga, ayat-ayat yang tidak berhubungan secara hermeneutis berjumlah 5 ayat yang terdiri dari QS. ali Imran/2: 18-19, QS. alA'rāf/7: 54, QS. al-Ahquāf/46: 29-30.

\section{Simpulan}

Dari analisa penelitian yang telah dilakukan penulis, maka dapat diambil kesimpulan bahwa: Pertama, Ayat-ayat yang digunakan dalam praktek Quranic Healing secara akumulatif berjumlah 75 ayat yang terdiri dari QS. al-Fātiḥah/1: 1-7, QS. al-Baqarah/2: 102-103, 255, 284-286, QS. ali Imrān/3: 18-19, QS. alNisā/4: 56, QS. al-A'rāf/7: 54, 117-122, QS. Yūnus/10: 57, 81-82, QS. Tāha/20: 69-70, QS. al-Mukminūn/23-115-118, QS. al-Ṣāffāt/37: 1-10, QS. al-Aḥāf/46: 29-32, QS. al-Raḥmān/55: 33-36, QS. al-Hasyr/59: 21-24, QS. alJīn/72: 1-9, QS. al-Ikhlaṣ/112: 1-4, QS. al-Falaq/113: 1-5 dan QS. alNās/114: 1-6.

Kedua, Secara umum adanya keutamaan ayat-ayat yang digunakan dalam praktek Quranic Healing. Hal ini tidak terlepas bahwa al-Qur'an juga berfungsi sebagai penyembuh (Syifä) (QS. alIsrā/17: 82). Seperti QS. alBaqarah/2: 255 (ayat kursi) yang punya keutamaan sebagaimana telah diberitakan oleh Nabi Muhammad Saw, dan karenanya ayat ini dianggap penting dalam pengobatan. Terlebih Allah Swt akan menjaga orang yang membacanya dari segala keburukan, bahaya dan penyakit. Dengan demikian pembacaan ini merupakan tindakan proteksi dan preventif, karena sesungguhnya ayat kursi ini mempunyai efek yang kuat sekali dalam menjaga 
manusia dari keburukan segala penyakit dan macam-macamnya (walāyaūduhu hifZuhumā wahua al-'Alì al-'AZìm)

Ketiga, Dalam temuan penulis, ayat-ayat yang secara implisit berhubungan dengan penyakit berjumlah 50 ayat yang terdiri dari QS. al-Fātihah/1: 1-7, QS. a-Baqarah/2: 255, 284-286, QS. al-A'rāf/7: 117122, QS. al-Isrā/17: 82, QS. Tāhā/20: 69, QS. al-Mukminūn/23: 115118, QS al-S\{āffāt/37: 1-10, QS. alHasyr/59: 21-24, QS. al-Ikhlaș/112: 1-4, QS. al-Falaq/113: 1-5 dan QS. alNās/114: 1-6. Adapun ayat-ayat yang secara eksplisit berhubungan dengan peyakit yang disembuhkan berjumlah 20 ayat yang terdiri dari QS. alBaqarah/2: 102-103, QS. al-A'rāf/7: 54-56, QS. Yunūs/10: 57, 81-82, QS. alRaḥmān/55: 3336 dan QS. Jinn/72: 1-9. Sedangkan ayat-ayat yang tidak berhubungan secara hermeneutis berjumlah 5 ayat yang terdiri dari QS. ali Imran/2: 18-19, QS. al-A'rāf/7: 54, QS. al-Aḥqāf/46: 29-30 


\section{Daftar Pustaka}

al-Khūli, Amīn, Manāhij Tajdìd fì al-Nahw wa al-Baläghah wa al-Tafsìr wa al-Ad (Mesir: Dār al-Ma'rifah, 1961).

Abū Zayd, Nasir, Tekstualitas al-Qur'an,terj. Khoiron Nahdiyyin, (Yogyakarta: LKIS, 2000).

al-Zarqanī, Muḥammad Abduh al-'AZīm, Manāhil al-'Irfān fì̀ 'Ulūm alQur'ān, Beirut: Dār al-Fikr, t.t

Ahmad, Perdana, Teknologi Penyembuhan Qur'ani, (ttp: Quranic Healing Indonesia, $\mathrm{tt}$ ).

Ahimsa, Heddy Shri, The Living al-Qur'an: Beberapa Perspektif Antropologi, dalam Jurnal Walisongo, Volume 20, Nomor1, Mei 2012.

al-Azharī, Tahzīb al-Lughah, (ttp: Mauqi al-Waraq, tt).

Abādi, Syarif al-Haq al-'AZīm, 'Aūn al-Ma'būd alā Syarh Sunan Abī Dāud, Juz. I, (Beirūt: Dār Ibn Hazm, 2005).

al-Naisābūrī, Muhammad bin Abdullah Abu Abdullah al-Ḥākim, alMustadrak ala Sabīhaini, (Bairut: Dār al-Kutub al-Ilmiyyah, 1990).

A Partanto, Pius, Kamus Ilmiah Populer, (Surabaya: Arkola: 1994), Andriawan, Didik, Penggunaan ayat al-Qur'an sebagai Pengobatan: Studi Living al-Qur'an pada Praktik Pengobatan Dr. KH. Komari Saifullah pada Pesantren Sunan Kalijaga Desa Pakucen Kecamatan Patianworo Kabupaten Nganjuk. Skripsi Fakultas Ushuluddin UIN Sunan Kalijaga Yogyakarta, 2013

Anwar, Ahmad, Pembacaan Ayat-ayat al-Qur'an dalam Prosesi Mujahadah di Pondok al-Luqmaniyah Umbul Harjo Yogyakarta. Skripsi Fakultas Ushuluddin UIN Sunan Kalijaga Yogyakarta, 2014.

Badri, Surat Tabārak: Pendinding dari Siksa Kubur, alih bahasa oleh $H$. Nurullah dan Fauzan, (Surabaya: Aneka Pustaka Islam, 1991)

Bakker, Anton, Kamus Filsafat, (Yogyakarta: Kanisius, 1992 , Metode-Metode Filsafat (Jakarta: Ghalia Indonesia, 1994)

Esack, Farid, The Qur'an: A Short Introduction, (England: Oneworld Publication, 2002).

, Samudera al-Qur'an, terj. Nuril Hidayah, (Yogyakarta: Diva Press, 2008).

Fathurrohim, Tradisi Membaca Surat al-Jin Sebelum Menempati Rumah Baru pada Masyarakat Margasari Kecamatan Sidareja Kabupaten Cilacap (Studi Living al-Qur'an), Skripsi Fakultas Ushuluddin UIN Sunan Kalijaga Yogyakarta, 2010. 
Halim, Wahidin Memahami al-Qur'an, Menjelajah Islam dan Mengenang Sejarah Musabaqah Tilawahal-Qur'an, (Jakarta: PT. Pendulum, 2006).

M. Quraish Shihab, Kaidah Tafsir, (Tangerang: Lentera Hati, 2013).

Hakim, Adz Zikrul, Do’a dan Cara Praktis Ruqyah Mandiri, (Jakarta: Giya Tazkiyah Qurani, 2015).

Hasyimi, Ahmad. Jawahir al-Balaghah. (Beirut: Dâr al-Fikri. 1994).

Ibn ManZūr, Muhammad ibn Mukarram , Lisān al-'Arab, (Beirūt: Dār S\{ādir, $\mathrm{tt})$.

Kathīr, Ibn, Tafsìr al-Qur'ān al-'Azìm li al-Hāfiz Ibn Kaslìr, Juz. 5, (Qāhirah: Dār al-Hadīsl, 2002).

Kartono, Kartini ,Pengantar Metodologi Riset Sosial (Bandung: Mandar Maju, 1996).

Kaheel, Abdeddaem, Obati Dirimudengan al-Qur'an: Kajian Ilmiah Pertama yang Melegalkan Pengobatan dengan al-Qur'an, terj. Moh. Syairozi, (Tanggerang Selatan: Iniperbesa, 2015).

Middelton, John, "The Religious System" dalam A. Handbook of Method in Cultural Anthropolgy, ed. Raul Naroll, (New York: Columbia University Press, 1973).

Muhammad, dkk, Metodologi Penelitian Livingal-Qur'an dan Hadis, ed Sahiron Syamsuddin, (Yogyakarta: Teras, 2007).

Mohtador, Mohamamad, Pemaknaan ayat-ayatal-Qur'an dalam Mujāhadah (Studi Living al-Qur'an Pondok Pesantren Krapyak Komplek al-Kandiyas), Tesis UIN Sunan Kalijaga Yogyakarta, 2012.

Moeloeng, Lexy J., Metodologi Penelitian Kualitatif, (Bandung: Remaja Rosdakarya, 2007).

M. Federspiel, Howard, Kajian al-Qur'an di Indonesia dari Mahmud Yunus Hingga Quraish Shihab, (Bandung: Mizan, 1996).

Miles, Matthew dan A, Michael Huberman, Analisis Data Kualitatif: Buku Sumber Tentang Metode-metode Baru, (Jakarta: UI Press, 1992).

Rafiq, Ahmad, Pembacaan yang atomistic terhadap al-Qur'an Antara Penyimpangan dan Fungsi, Jurnal Studi Ilmu al-Qur'an dan Hadis, Vol. 5, No. 1 Januari 2004

Ratna, Nyoman Kutha, Teori, Metode, dan Teknik Penelitian Sastra: Dari Strukturalisme hingga Post-strukturalisme (Yogyakarta: Pustaka Pelajara, 2006),

Suprayogo, Imam , Penelitian Sosial-Agama, (Bandung: Remana Rosyda Karya, 2003). 
Satori Djam'an, dan Aam Komariah, Metodologi Penelitian Kualitatif,

(Bandung: Alfabeta, 2013),

Suharsimi Arikunto, Prosedur Penelitian Suatu Pendekatan Praktik,

(Yogyakarta: Rineka Cipta, 2010).

Salim, Sya'ban Ahmad, Eksiklopedia Pengobatan Islam, (Jakarta: Pustaka Arafah, 2012).

Supranto, J, Metode Riset, Aplikasinya dalam Pemasaran, (Jakarta: Lembaga Riset Fak. Ekonomi UI, 1986).

Sugiyono, Metode Penelitian Kuantitatif, Kualitatif, (Bandung: Alfabeta, 2012).

Setiawan, Muhammad Nur Kholis, al-Qur'an Kitab Sastra Terbesar,

(Yogyakarta: elsaq Press, 2006)

Ulum, Khoirul, Pembacaan al-Qur'andi Lingkungan Masyarakat

Jawa Timur (Studi Masyarakat Grujugan Bondowoso), Tesis PPS UIN Sunan Kalijaga Yogyakarta, 2009.

Warsito, Hermawan, Pengantar Metode, (Jakarta: Gramedia, 1993).

Zuhaili, Wahbah, dkk, al-Qur'an Seven in One, terj. Imam Ghazali Masykur. $d k k$, (PT. Almahira: Jakarta, 2009).

\section{Internet}

http://wahdah.or.id/

http://rumasvho.com.

http://quranic-healing.org

CD Ensiklopedia Hadis, Kitab 9 Imam,, (Lidwa Pusaka-Software,tt).

CD Maktabah Syamilah

\section{Endnotes}

1 Muhammad Chirzin, "Mengungkap Pengalaman Muslim Berinteraksi dalam al-Qur'an" dalam Metodologi Penelitian Living al-Qur'an dan Hadis, ed Sahiron Syamsuddin, (Yogyakarta: Teras, 2007), hal. 12.

2 Dalam realitas sosial kehidupan muslim, tindakan yang dimaksud penulis dapat disaksikan begitu dekat oleh kita. Pengalaman berinteraksi dengan alQur'an terlihat begitu beragam dari sekedar membaca al-Qur'an baik secara sendiri maupun berjamaah (baca: komunitas), kelompok penggiat kajian tafsir al-Qur'an, penghafal al-Qur'an, mengusir makhluk halus dengan alQur'an, praktek ruqyah, hingga menjadikan ayat-ayat al-Qur'an tertentu dan menjadikannya sebagai hiasan rumah, hiasan masjid dan sebagainya. Semua yang dicontohkan tersebut merupakan sebagian dari bentuk terapan interaksi muslim dengan alQur'an.

3 Dalam hal ini, mengutip ungkapan Farid Esack dalam bukunya "A Short Introduction", menyatakan bahwa al-Quran mampu memenuhi banyak fungsi di dalam kehidupan muslim. Al-Quran, secara teologis diyakini sebagai kitab agama yang sangat istimewa di 
mata penganutnya. Hingga keragaman bentuk interaksi yang ada antara al-Quran dan penganutnya adalah juga sebab tersebut selain pemaknaan yang lahir dari teks itu sendiri. Farid Esack, The Qur'an: A Short Introduction, (England: Oneworld Publication, 2002), hal. 5.

4 Lihat Tekstualitas al-Qur'an, terj. Khoiron Nahdiyyin, (Yogyakarta: LKIS, 2000), hal.1.

5 (QS. al-Fușṣilāt/41: 44). Lihat Wahbah Zuhaili, dkk, al-Qur'an Seven in One, terj. Imam Ghazali Masykur. dkk, (PT. Almahira: Jakarta, 2009).

6 Telah menceritakan kepada kami Abdullah bin Yusuf Telah mengabarkan kepada kami Malik dari Ibnu Syihab dari Urwah dari Aisyah ra, bahwasanya; Apabila Rasulullah saw menderita sakit, maka beliau membacakan al Mu'awwidzaat untuk dirinya sendiri, lalu beliau meniupkannya. Dan ketika sakitnya parah, maka akulah yang membacakannya pada beliau, lalu mengusapkan dengan menggunakan tangannya guna mengharap keberkahannya. Lihat CD Ensiklopedia Hadis Sembilan, HR. Bukhari Nomor: 4629.

7 Lihat www.quranic-healing.org dan www.quranic-healing.com.

8 Kartini Kartono, Pengantar Metodologi Riset Sosial (Bandung: Mandar Maju, 1996), hal. 20.

9 Nyoman Kutha Ratna, Teori, Metode, dan Teknik Penelitian Sastra: Dari Strukturalisme hingga Post-strukturalisme (Yogyakarta: Pustaka Pelajar, 2006), hal. 53-54. Metode ini juga menyelidiki dengan menuturkan, menganalisa data-data dan menjelaskannya. Hermawan Warsito, Pengantar Metode, (Jakarta: Gramedia, 1993). Lihat juga Anton Baker, Metode-Metode Filsafat (Jakarta: Ghalia Indonesia, 1994), hal. 17.

10 Istilah fenomenologi berasal dari bahasa Yunani Pahainomenon yang secara harfiah berarti "gejala" atau "apa yang telah menampakkan diri” sehingga nyata bagi kita. Fenomenologi sebagai metode berfikir ilmiah, merupakan cabang dari aliran filsafat, yaitu filsafat eksistensial. Lihat Imam Suprayogo, Metodologi Penelitian Sosial-Agama, (Bandung: Remana Rosyda Karya, 20030), hal. 102.

11 Sugiyono, Memahami Penelitian Kualitatif..., , hal. 274.

12 Matthew Miles dan A, Michael Huberman, Analisis Data Kualitatif: Buku Sumber Tentang Metode-metode Baru, (Jakarta: UI Press, 1992), hal, 20.

13 Wawancara dengan Abū Zakwān, 30 Agustus 2015 di kediamannya Jl. Hibrida 3 Kota Bengkulu.

14 Wawancara dengan Abū Zakwān, 30 Agustus 2015 di kediamannya Jl. Hibrida 3 Kota Bengkulu.

15 Wawancara dengan Abū Furqān, 7 September 2015 di Kantor BAZ Propinsi Bengkulu. 16 Wawancara dengan Nopran,

16 September 2015, pukul 16.30 wib di Masjid al-Nūr Lingkar Barat Kota Bengkulu.

17 Ahmad Rafiq, Pembacaan yang atomistic terhadap al-Qur'an Antara Penyimpangan dan Fungsi, Jurnal Studi Ilmu al-Qur'an dan Hadis, Vol. 5, No. 1 Januari 2004, hal. 4.

18 Ahmad Rafiq, Pembacaan yang atomistic..., hal. 4.

19 "Sesungguhnya Kami menurunkannya berupa Al Quran dengan berbahasa Arab, agar kamu memahaminya." Lihat Wahbah Zuhaili, dkk, al-Qur'an Seven in One, terj. Imam Ghazali Masykur. dkk, (PT. Almahira: Jakarta, 2009), hal. 236. Disebutkan bahwa Allah 
Swtmenurunkan al-Qur'an dengan bahasa Arab agar manusia mempelajari maknanya (memaknai) dan memahami isinya untuk membangun kepribadian individu dan masyarakat.

20 Diantara pemaknaan umat Islam terhadap al-Qur'an adalah al-Qur'an dimaknai sebagai "Kitab," sebagai "Buku," sebagai "Bacaan", al-Qur'an dimaknai sebagai sebuah kitab yang istimewa, sebagai kitab suci (sacred), al-Qur'an sebagai kumpulan petunjuk (Huda), alQur'an merupakan obat jasmani dan al-Qur'an dimaknai sebagai sarana perlindungan. Lihat The Living al-Qur'an: Beberapa Perspektif Antropologi, .hal. 242.

21 Heddy Shri Ahimsa Putra, The Living al-Qur'an: Beberapa Perspektif Antropologi, dalam Jurnal Walisongo, Volume 20, Nomor1, Mei 2012, hal. 246. 